\title{
BAHASA INDONESIA DALAM BELITAN MEDIA SOSIAL: DARI CABE-CEBEAN HINGGA TAFSIR AL-MAIDAH 51*
}

\author{
Umar Mansyur ${ }^{* *}$ \\ Fakultas Sastra, Universitas Muslim Indonesia \\ umar.mansyur@umi.ac.id
}

\begin{abstract}
Abstrak
Media sosial dalam praktiknya menggunakan bahasa sebagai medium utama untuk saling berinteraksi. Bahasa menjadi prasyarat mutlak agar komunikasi para penggunanya dapat berjalan lancar. Dalam konteks Indonesia, bahasa Indonesia berkedudukan sebagai bahasa nasional dan bahasa negara. Salah satu fungsinya digunakan sebagai alat pengembangan kebudayaan nasional, ilmu pengetahuan dan teknologi. Kebudayaan nasional yang beragam, rasanya tidaklah mungkin dapat disebarluaskan kepada masyarakat dengan menggunakan bahasa lain, selain bahasa Indonesia. Hal ini juga berlaku dalam penyebarluasan ilmu pengetahuan dan teknologi modern, termasuk dalam penggunaan media sosial. Tidak dapat dimungkiri perkembangan media sosial yang kini dapat diakses dengan mudah oleh hampir seluruh kalangan masyarakat telah memberikan banyak manfaat, namun juga menjadi ancaman terhadap eksistensi bahasa Indonesia. Misalnya, fenomena bahasa alay dan memudarnya etika dalam bertutur. Variasi-variasi dalam bahasa alay mayoritas dipopulerkan oleh kalangan remaja di media sosial. Dan harus diakui bahwa eksistensi bahasa gaul tersebut tampaknya mulai merongrong kewibawaan bahasa Indonesia dari segi kaidah tata bahasa. Selain itu, media sosial kadang hanya digunakan sebagai wadah mengekspresikan kemarahan dan caci-maki, serta tulisan-tulisan yang memuat konten pornografi dan provokasi, sehingga yang terjadi adalah semakin memudarnya etika bersopan santun dalam bertutur. Terhadap persoalan tersebut, beragam upaya dapat dilakukan dalam membina dan mengembangkan bahasa Indonesia. Salah satunya melalui pendekatan pembelajaran bahasa Indonesia yang menggunakan media sosial dalam membantu siswa memahami kaidah tata bahasa Indonesia yang baik dan benar. Hal ini dapat dilakukan karena media sosial telah menjadi bagian dari kehidupan masyarakat Indonesia, terutama kalangan remaja. Selain itu, juga harus ditanamkan sejak dini rasa cinta dan bangga terhadap bahasa Indonesia dengan cara membiasakan diri menggunakan bahasa Indonesia secara baik dan benar sesuai dengan kaidah dan konteks yang berlaku.
\end{abstract}

Kata Kunci : Bahasa Indonesia dan Media Sosial

\section{Pendahuluan}

Laju perkembangan informasi dan teknologi dalam bingkai globalisasi yang semakin pesat turut berpengaruh pada meningkatnya penggunaan media sosial dalam masyarakat. Beberapa media sosial yang berkembang saat ini, seperti facebook dan twitter, telah melahirkan gaya hidup baru dalam kehidupan sosial bermasyarakat. Dengan menggunakan media sosial, seseorang dapat menjalin pertemanan dan saling berinteraksi dengan siapapun, kapanpun, dan di mana saja.

\footnotetext{
* Disajikan pada Seminar Bulan Bahasa FIB-UNHAS Tahun 2016 di Makassar, 11-12 November.

** Dosen jurusan Pendidikan Bahasa dan Sastra Indonesia, Universitas Muslim Indonesia.
} 
Tentunya keberadaan media sosial telah memberikan banyak manfaat kepada para penggunanya. Namun demikian, pengaruh media sosial di Indonesia berdampak pada kurang terbinanya masyarakat pengguna media sosial terhadap pemakaian bahasa Indonesia secara baik dan benar. Belakangan ini, perkembangan penggunaan bahasa Indonesia di media sosial justru menunjukkan tren yang negatif jika dikaitkan dengan usaha pemerintah dalam membina dan mengembangkan bahasa Indonesia. Sebagai contoh adalah bahasa gaul ataupun bahasa alay.

Bahasa alay bisa dikatakan sebagai produk dari ragam bahasa sosial tertentu yang bersifat nonbaku yang berkembang di media sosial. Secara mayoritas, variasi-variasi bahasa seperti ini dipopulerkan oleh kalangan remaja. Dan harus diakui, eksistensi bahasa alay tampaknya mulai merongrong kewibawaan bahasa Indonesia dari segi kaidah tata bahasa. Sementara, diketahui bersama bahasa Indonesia telah menjadi identitas persatuan dan kebanggan bangsa Indonesia paling tidak sejak tahun 1928 pada momentum Sumpah Pemuda 88 tahun silam.

Pada konteks yang lain, Indonesia dikenal dengan bangsa yang ramah dan berbudi pekerti luhur, baik dalam berperilaku maupun dalam bertutur. Namun, akhirakhir ini, pengaruh media sosial tampaknya juga berefek pada memudarnya etika dalam bertutur di tengah masyarakat. Sudah sering kita baca dan saksikan, banyak kalangan yang menggunakan media sosial sebagai wadah untuk mengekspresikan kemarahan, tulisan-tulisan yang memuat konten pornografi dan provokasi. Misalnya yang sedang hangat, kasus dugaan penistaan agama yang muasalnya dari rekaman perkataan secara lisan seorang pejabat yang menyentil persoalan tafsir Surah Al-Maidah ayat 51.

Fenomena-fenomena tersebut di atas tentu saja tidak bisa dibiarkan begitu saja karena berimbas pada rusaknya mental para generasi muda. Dalam hal ini, ingin ditunjukkan bahwa bahasa bukan hanya urusan tuturan semata, melainkan juga menyangkut karakter dan kepribadian yang bertutur. Generasi yang berbudi pekerti luhur tercermin dari bahasanya yang santun dan tertata, dan bahasa suatu bangsa menjadi identitas dan kepribadian bangsa itu.

\section{Media Sosial dan Pengaruhnya}

Perkembangan dunia informasi dan telekomunikasi yang sudah demikian pesatnya membuat jarak tak lagi menjadi masalah. Jejaring sosial tentu saja menjadi media yang paling populer digunakan. Facebook, twitter, dan instagram merupakan aplikasi media sosial yang banyak digunakan untuk memperluas pergaulan pertemanan dalam lingkup global yang terhubung melalui jaringan internet. Di Indonesia dan beberapa negara lain, pengguna situs sosial media mayoritas dinikmati oleh kalangan remaja. Sementara secara psikologi, pada usia remaja menjadi fase pertumbuhan manusia yang cenderung labil dan rentan terhadap berbagai macam pengaruh. Sekaitan dengan hal tersebut, pengaruh media sosial dapat berwujud dalam gaya berbahasa dan juga terhadap gaya berpakaian (fashion).

Data yang diperoleh (Kemkominfo, 2013) menunjukkan bahwa pengguna internet di Indonesia saat ini sudah mencapai 63 juta orang. Dari jumlah tersebut, 95 persen di antaranya menggunakan internet untuk mengakses media sosial. Situs media sosial yang paling banyak diakses adalah facebook dan twitter. Secara internasional, Indonesia menempati peringkat 4 pengguna facebook terbesar, setelah Amerika Serikat, Brazil, dan India. Sementara itu, Indonesia menempati peringkat 5 pengguna twitter terbesar di dunia. Posisi Indonesia hanya kalah dari Amerika Serikat, Brazil, Jepang, dan Inggris. Akan tetapi, menurut Sularto (2013), jika dilihat dari jumlah twit (kicauan) yang dilepaskan setiap harinya, DKI Jakarta didaulat menjadi ibu kota twitter dunia karena 
berhasil menduduki peringkat pertama, mengalahkan kota-kota besar lainya, seperti Tokyo, London, Sao Paulo, dan New York.

Tidak dapat dimungkiri perkembangan media sosial yang kini dapat diakses dengan mudah oleh hampir seluruh kalangan masyarakat telah memberikan banyak manfaat bagi para penggunanya, namun tidak menutup kemungkinan juga dapat menjadi suatu ancaman. Oleh beberapa ahli, ancaman ini salah satunya berefek pada aspek kebahasaan yang dapat mengancam eksistensi dan orisinalitas bahasa Indonesia. Untuk itu, sebagai warga Negara Indonesia hendaknya merasa bangga karena memiliki bahasa Indonesia yang telah dijadikan sebagai perekat atas berbagai suku dan bahasa yang beragam. Maka atas dasar kebanggaan itu, bahasa Indonesia harus terus dipelihara.

\section{Ragam Bahasa Sosial: Kasus Bahasa Alay}

Ragam bahasa diartikan sebagai variasi bahasa menurut pemakaiannya, topik yang dibicarakan, hubungan pembicara dengan teman bicara, serta situasi pembicaraan. Menurut Alwi dkk. (2003), meskipun ragam bahasa Indonesia beraneka macam, tetapi masih tetap disebut bahasa Indonesia karena masing-masing berbagi inti sari bersama yang umum, yaitu ciri dan kaidah tata bunyi, pembentukan kata, dan tata makna umumnya masih sama. Itulah sebabnya masih dapat dipahami jika ada orang yang berbahasa Indonesia namun ditemukan beberapa perbedaan dalam perwujudan bahasa Indonesianya.

Ragam sosial adalah ragam bahasa yang sebagian norma dan kaidahnya didasarkan atas kesepakatan bersama dalam lingkungan sosial yang lebih kecil dalam masyarakat. Ragam sosial tidak jarang dihubungkan dengan tinggi atau rendahnya status kemasyarakatan lingkungan sosial seseorang. Dalam hal ini, ragam baku nasional dapat berfungsi sebagai ragam sosial yang tinggi, sedangkan ragam baku daerah atau ragam sosial yang lain merupakan ragam sosial dengan nilai kemasyarakatan yang rendah.

Berbahasa Indonesia secara baik dan benar memiliki konsekuensi logis terkait dengan pemakaiannya sesuai dengan situasi dan konteks pembicaraan. Pada situasi formal, menggunakan bahasa Indonesia yang benar menjadi prioritas utama dan pemakaiannya sering menggunakan bahasa baku. Terkadang yang menjadi permalasahan adalah munculnya gejala bahasa, seperi interferensi bahasa gaul, yang tanpa disadari turut dipakai dalam berbahasa Indonesia ragam resmi. Hal ini mengakibatkan bahasa Indonesia yang digunakan menjadi tidak baik.

Interferensi bahasa gaul terhadap bahasa Indonesia saat ini sudah cukup memprihatinkan. Bahasa gaul yang boleh dibilang masih tetap eksis bahkan terus berkembang sampai saat ini adalah bahasa alay. Sejarah lahirnya bahasa alay oleh para peneliti disebutkan sangat berkaitan dengan perkembangan teknologi informasi dan telekomunikasi. Bahasa ini pertama kali beredar melalui pesan singkat atau SMS. Berawal dari niat untuk menyingkat kata-kata lalu menggantinya dengan angka yang serupa bentuknya dengan beberapa huruf, dengan tujuan menghemat jumlah karakter dan biaya pengiriman SMS. Tetapi kemudian, bahasa yang mayoritas penggunanya adalah kalangan remaja ini terus berkembang yang tidak lagi sebatas untuk menyingkat dan menghemat SMS semata, namun juga sudah merambah pada aktivitas chatting di media sosial, facebook dan twitter. Bahasa alay kemudian berkamuflase menjadi sebuah ragam bahasa sosial yang aneh, sedikit konyol, dan cenderung sengaja dilebih-lebihkan atau dalam bahasa alay dikenal dengan istilah 'lebay'. Contohnya: "G4g klwar $m L 4 m ~ m N g u$ G4g pa2.. G4g pnY4 pC4r G4g pa2, 4saL pnY4 dullt bNya4k, H4rta, t4hTa, clNta, h4h4h4.. 4sy33eekk.. Cemunguutt.. Eaa..."

Selanjutnya, seiring dengan zaman yang terus berkembang, bahasa alay kini tidak hanya sebatas pada persoalan variasi dalam menuliskan huruf atau kata saja, tetapi juga 
sudah berkembang pada aspek semantik, misalnya istilah 'cabe-cabean' dan 'terongterongan'. Cabe-cabean merupakan makna khiasan yang penggunaanya dikonotasikan kepada perempuan usia muda yang alay (baca: cewek yang reaksinya berlebih-lebihan terhadap sesuatu). Secara denotatif, kata 'cabe' itu sendiri adalah istilah lain dari kata 'cabai' yang berarti tanaman perdu yang buahnya berbentuk bulat panjang dengan ujung meruncing, apabila sudah tua berwarna merah kecokelat-cokelatan atau hijau tua, berisi banyak biji yang rasanya pedas (KBBI, 2008).

Pada mulanya, istilah ini digunakan untuk menggambarkan fenomena kelakukan remaja yang tergabung dalam kelompok balapan motor liar, dan si pemenang balapan tersebut dapat 'mengencani' si gadis cabe-cabean. Namun, kini istilah cabe-cabean cakupannya meluas pada perilaku remaja perempuan (usia SMP-SMA) yang dicirikan dengan pakaian yang minim dan ketat, suka menggunakan nama-nama aneh pada akun media sosialnya, centil, serta gemar boncengan motor bertiga tanpa memakai helm sambil bermain telepon pintar. Lewat media sosial, pun istilah cabe-cabean menjadi popular bagi banyak kalangan masyarakat yang dipakai untuk mengolok-olok temannya, seperti ungkapan "Dasar cewek cabe-cabean...".

Disadari bersama bahwa bahasa alay kini telah menjadi ragam bahasa sosial tertentu yang dipakai dalam dunia pergaulan kalangan remaja. Mayoritas para remaja enggan berbahasa Indonesia dengan baik dan benar karena mereka menganggap terlalu formal dan ketinggalan zaman. Terlebih munculnya anggapan bahwa variasi-variasi bahasa tersebut adalah bahasa anak/remaja yang gaul, maka mereka yang tidak menggunakannya akan danggap sebagai anak yang kuno atau ketinggalan zaman. Hal ini disebabkan kecenderungan para remaja yang selalu menarik perhatian orang-orang di sekitarnya dan mengukuhkan diri sebagai kelompok sosial tertentu dalam pergaulan masyarakat.

Maka dari itu, sangat beralasan jika muncul kekhawatiran banyak pihak terhadap maraknya penggunaan bahasa alay di media sosial yang dianggap sebagai ancaman yang serius terhadap kaidah tata bahasa Indonesia. Jika hal ini dibiarkan terus menerus dan tidak diupayakan pencegahan, lama-kelamaan bahasa gaul inipun akan menjadi kesepakatan bahasa yang arbiter. Alhasil, pudarlah sudah keorisinilan bahasa Indonesia itu sendiri. Oleh karena itu, untuk menghidari hal-hal tersebut, diperlukan upaya yang maksimal untuk menanamkan dan menumbuhkan kecintaan terhadap pemahaman bahasa Indonesia. Salah satu upaya yang telah terbukti efektif adalah pendekatan pembelajaran bahasa Indonesia dengan menggunakan media sosial dalam membantu siswa memahami kaidah tata bahasa Indonesia yang baik dan benar. Hal ini dilakukan karena media sosial sudah menjadi bagian dari kehidupan masyarakat Indonesia, terutama kalangan remaja.

\section{Ragam Bahasa Lisan dan Tulis: Kasus Surah Al-Maidah ayat 51}

Bahasa Indonesia ragam lisan sangat berbeda dengan bahasa Indonesia ragam tulis. Tidak semua ragam tulis dapat dilisankan, begitupun sebaliknya, karena kaidah yang berlaku bagi ragam lisan belum tentu berlaku bagi ragam tulis. Kedua ragam ini berbeda satu sama lain. Ragam lisan menghendaki adanya orang kedua atau teman berbicara yang berada di depan pembicara, sedangkan ragam tulis tidak harus ada teman bicara yang berada di depan. Dalam ragam lisan, unsur-unsur fungsi gramatikal seperti subjek, predikat, dan objek, tidak selalu dinyatakan. Unsur-unsur itu kadang-kadang dapat ditinggalkan. Hal ini disebabkan oleh bahasa yang digunakan dibantu oleh gerak, mimik, pandangan, atau anggukan.

Ragam tulis perlu lebih terang dan lebih lengkap daripada ragam lisan. Fungsifungsi gramatikal harus nyata karena ragam tulis tidak mengharuskan orang kedua berada di depan pembicara. Kelengkapan ragam tulis menghendaki agar orang yang "diajak 
bicara" mengerti isi tulisan. Selanjutnya, menurut Alwi dkk. (2003) ragam lisan sangat terikat pada kondisi, situasi, ruang, dan waktu, sedangkan ragam tulis tidak terikat pada kondisi tersebut. Apa yang dibicarakan secara lisan di dalam sebuah ruang kuliah hanya akan berarti dan berlaku untuk waktu itu saja. Apa yang diperbincangkan dalam ruang diskusi tentang topik tertentu belum tentu dapat dimengerti oleh orang yang berada di luar ruangan itu. Selain itu, ragam lisan dipengaruhi oleh tinggi rendahnya dan panjang pendeknya suara, sedangkan ragam tulis dilengkapi dengan tanda baca, huruf besar, dan huruf miring.

Berbicara mengenai kasus tafsir Surah Al-Maidah ayat 51 yang berkaitan dengan suksesi pemilihan gubernur di DKI Jakarta, penulis memfokuskan persoalan ini pada konteks ragam bahasa lisan dan tulisan. Maksudnya, berdasarkan teori yang telah diuraikan sebelumnya bahwa bahasa Indonesia ragam lisan sangat berbeda dengan bahasa Indonesia ragam tulis. Artinya, dalam konteks yang berbeda, maksud sebuah pembicaraan dapat mengalami perbedaan makna berdasarkan konteks penyampainnya. Dalam hal ini, faktor media sosial dan faktor bahasa yang digunakan menjadi sangat penting untuk dicermati bersama.

Dalam perkembangannya, peran media telah menjadi alat politik atau kampanye yang paling mujarab dalam menggiring opini masyarakat. Namun dalam beberapa kasus, media sosial menjadi ajang provokasi dan caci-maki kepada sesama pendukung calon pemimpin tertentu. Selain itu, di dunia hiburan tanah air, juga bermunculan fenomena para penghujat (haters) kepada artis-artis tertentu. Oleh karena penggunaan media sosial yang sudah tidak mengenal batas, maka sudah banyak pihak yang dipidanakan atas dasar pencemaran nama baik yang memang sudah diatur dalam Undang-Undang Informasi dan Transaksi Elektronik (UU ITE).

Sebelum melangkah lebih jauh, alangkah baiknya jika kasus ini dipisahkan dalam dua konteks yang berbeda, yakni (1) teks tertulis Surah Al-Maidah ayat 51 yang ditafsirkan, dan (2) rekaman (lisan) ucapan Basuki Tjahaja Purnama yang menyentil tafsiran Surah Al-Maidah ayat 51. Klasifikasi ini dilakukan agar dapat diketahui khalayak bahwa rupanya ragam lisan dan tulis dalam bahasa Indonesia sangat penting diperhatikan sebelum mengeluarkan argumen terhadap suatu permasalahan di media sosial, terutama untuk menghindari kasus hukum yang bisa menimpa kapan saja.

Pada konteks yang pertama, sudah diketahui bersama bahwa pada dasarnya sebuah teks cenderung potensial dimaknai berbeda oleh pembaca. Terutama jika yang dikaji adalah kitab suci Al-Quran yang memiliki kandungan arti yang sangat dalam, sehingga sangatlah wajar jika banyak dari kalangan ahli tafsir sendiri yang berbeda pandangan soal kandungan dari ayat tadi. Akan tetapi, tidak juga semua ayat-ayat dalam Al-Quran menimbulkan tafsiran yang berbeda. Bahwa kebenaran Al-Quran sudah tidak bisa ditawar lagi merupakan keniscayaan bagi seorang muslim, dan penulis tidak akan terlalu dalam masuk ke dalam wilayah itu. Namun, yang menjadi masalah jika menggunakan bahasa tafsiran yang keliru di media sosial untuk mempolitisasi sebuah kasus, sehingga dampak buruknya meluas ke mana-mana.

Selanjutnya pada konteks yang kedua, arti dari Surah Al-Maidah ayat 51 adalah sebagai berikut: "Hai orang-orang yang beriman, janganlah kamu mengambil orangorang Yahudi dan Nasrani menjadi pemimpin-pemimpin(mu); sebahagian mereka adalah pemimpin bagi sebahagian yang lain. Barangsiapa di antara kamu mengambil mereka menjadi pemimpin, maka sesungguhnya orang itu termasuk golongan mereka. Sesungguhnya Allah tidak memberi petunjuk kepada orang-orang yang zalim." Berkaitan dengan ucapan Basuki Tjahaja Purnama yang salah satu potongannya berbunyi: “...dibohongin pakai Surat Al-Maidah 51 macam-macam...”, menurut Agung (2016) makna dalam Surah Al-Maidah ayat 51 sudah sangat jelas menyatakan bahwa ayat 
tersebut tidak bisa dijadikan alat untuk berbohong. Jadi, ketika Pak Basuki berkata dengan kalimat seperti itu, maka dipastikan memang dapat menyakiti umat Islam karena menempatkan Surah Al-Maidah ayat 51 sebagai "keterangan alat" yang didahului oleh predikat 'bohong'. Dan, menempelkan kata negatif (bohong) pada sesuatu yang suci adalah suatu kekeliruan (Agung, 2016).

Pada kasus ini, konteks pembicaraan berlangsung secara lisan, sehingga faktor kondisi, situasi, ruang, dan waktu saat pembicaraan itu berlangsung perlu dipertimbangkan. Pada ragam lisan, aspek nonkebahasaan, seperti gestur, intonasi suara, dan mimik si pembicara turut mendukung keseluruhan makna dari apa yang dibicarakan. Oleh karena itu, menganalisis kesalahan ucapan lisan seseorang hanya berdasar pada bukti rekaman saja agaknya masih belum cukup mengungkap realita yang sebenarnya. Diperlukan keterangan tentang seperti apa kondisi, suasana, dan konteks saat pembicaraan itu berlangsung, sehingga diperoleh sebuah kesimpulan yang komprehensif.

Terlepas dari kasus tafsiran Surah Al-Maidah ayat 51, menunjukkan bahwa faktor kebahasaan dan nonkebahasaan dalam berbicara menjadi satu kesatuan yang tidak dapat dipisahkan. Berbeda jika konteksnya adalah ragam tulis, maka maknanya akan lebih terang dan lebih lengkap karena dilengkapi unsur-unsur fungsi gramatikal. Hal ini dapat menjadi pelajaran bersama mengenai pentingya memilih dan menggunakan diksi yang tepat, sehingga di kemudian hari tidak menimbulkan polemik dan interpretasi yang beragam. Selain itu, terlebih dahulu perlu memilih diksi yang tepat dan memilah kontenkonten yang bermanfaat sebelum di-publish atau di-share ke media sosial agar terhindar dari hal-hal yang tidak diinginkan. Oleh karena itu, sebagai bangsa yang berbudi luhur sudah sepatutnya menggunakan bahasa Indonesia dengan baik dan benar dalam komunikasi sehari-hari dan juga dalam aktivitas di media sosial.

\section{Penutup}

Bahasa merupakan identitas dan kebanggaan suatu bangsa. Oleh karena itu, untuk membangun rasa percaya diri yang kuat, sebuah bangsa memerlukan identitas. Identitas sebuah bangsa dapat diwujudkan melalui bahasa. Sebagai lambang identitas nasional, bahasa Indonesia harus dijunjung tinggi, selain bendera dan lagu kebangsaan. Di dalam pelaksanaan fungsi ini, bahasa Indonesia harus memiliki identitas tersendiri yang membedakannya dengan bahasa yang lain. Sebagai lambang kebanggaan nasional, bahasa Indonesia mencerminkan nilai-nilai sosial budaya yang mendasari rasa kebanggaan. Bangsa Indonesia harus merasa bangga karena memiliki bahasa Indonesia sebagai bahasa pesatuan yang telah menyatukan berbagai suku bangsa yang berbeda. Maka atas dasar kebanggaan itu, bahasa Indonesia harus terus dipelihara dan dipertahankan.

Tentunya beragam upaya dapat dilakukan dalam mengembangkan bahasa Indonesia yang menjadi perhatian kita bersama sebagai sebuah bangsa yang berbudaya. Pusat Bahasa yang ditunjuk oleh negara sebagai lembaga yang berkepentingan mengawal pembinaan dan pengembangan bahasa Indonesia juga telah melakukan berbagai macam program agar masyarakat dapat menanamkan sejak dini rasa cinta dan bangga terhadap bahasa Indonesia dengan cara membiasakan diri menggunakan bahasa Indonesia secara baik dan benar sesuai dengan kaidah yang berlaku. Akan tetapi, usaha-usaha tersebut dirasa masih kurang berdaya membendung pesatnya efek negatif dari media sosial terhadap eksistensi bahasa Indonesia. Namun demikian, optimisme kebangsaan harus tetap tumbuh dan terus digalakkan, utamanya dalam menumbuhkan kecintaan dan kebanggan menggunakan bahasa Indonesia secara baik dan benar dalam berinteraksi, baik berkomunikasi di dalam lingkungan keluarga, di tengah masyarakat, dan juga dalam penggunaannya di media sosial. 


\section{Daftar Rujukan}

Agung, Billi. 2016. Membedah Sisi Linguistik Kalimat Pak Basuki, (Online), (https://brilliagung.com/, Diakses pada 23 Oktober 2016)

Alwi, Hasan, dkk. 2003. Tata Bahasa Baku Bahasa Indonesia. Jakarta: Balai Pustaka.

Chaer, Abdul. 2012. Linguistik Umum. Jakarta: Rineka Cipta.

Depdiknas. 2008. Kamus Besar Bahasa Indonesia (Edisi Keempat). Jakarta: Balai Pustaka.

Kemkominfo. 2013. Pengguna Internet di Indonesia 63 Juta Orang, (Online), (https://kominfo.go.id/, Diakses pada 22 Oktober 2016).

Keraf, Gorys. 2010. Diksi dan Gaya Bahasa. Jakarta: PT Gramedia Pustaka Utama.

Kompas. 2003. Dari Katabelece Sampai Kakus: Kumpulan kolom Bahasa Kompas. Jakarta: PT Kompas Media Nusantara.

Kridalaksana, Harimurti. 1993. Kamus Linguistik. Jakarta: Gramedia.

Nadya, Della. 2012. Pengaruh Media Terhadap Gaya Bahasa Remaja, (Online), (https://dellanadya.wordpress.com/, Diakses pada 22 Oktober 2016).

Strinati, Dominic. 2007. Popular Culture: Pengantar Menuju Teori Budaya Populer. Yogyakarta: Jejak.

Sularto, St. 2013. 50 Tahun Kompas Gramedia: Mengembangkan Indonesia Kecil. Jakarta: PT Kompas Media Nusantara. 